\title{
Crustacean plankton abundance in the Danube River and in its side arms in Hungary
}

\author{
Csaba VAdAdi-FülöP ${ }^{1}$, Levente Hufnagel ${ }^{2}$, György JABlonszKY ${ }^{1}$ \& Katalin ZsugA ${ }^{3}$ \\ ${ }^{1}$ Department of Systematic Zoology and Ecology, Eötvös Loránd University, Pázmány P. sétány 1/c, H-1117 Budapest, \\ Hungary; e-mail: vadfulcsab@gmail.com \\ ${ }^{2}$ Department of Mathematics and Informatics, Corvinus University of Budapest, Villányi út 29-33, H-1118 Budapest, \\ Hungary \\ ${ }^{3}$ Environmental and Water Research Institute (VITUKI), Kvassay út 1, H-1095 Budapest, Hungary
}

\begin{abstract}
The spatial distribution and seasonal dynamics of the crustacean zooplankton were studied in the Danube River and in its side arms near Budapest, Hungary. Microcrustaceans were sampled biweekly from October 2006 to November 2007 at eleven sites. Thermocyclops crassus, Moina micrura and Bosmina longirostris added up to $57.6 \%$ of the total density. Comparisons of the different water bodies stressed the separation of the eupotamal and parapotamal side arms. Densities in the side arms were one respectively two orders of magnitude higher as compared to the main channel, which was relatively poor in plankton. There were remarkable longitudinal and transversal variations in the abundance of the major zooplankton groups (cladocerans, adult copepods, copepodites, nauplii) and dominant species $(t$-test, $P<0.05)$. However, no general pattern was observed, the spatial distribution depended on the examined objects. There were statistically significant seasonal differences in zooplankton abundance (Tukey-test, $P<0.05$ ). Water residence time and water discharge were not found to be related to zooplankton abundance, but water temperature was positively correlated with microcrustacean density.
\end{abstract}

Key words: Copepoda; Cladocera; bootstrap; transversal sampling; side arm

\section{Introduction}

The spatio-temporal dynamics of riverine zooplankton has been investigated regularly, however, the spatial distribution of planktonic crustaceans and the factors regulating zooplankton abundance are often controversial, hence present paper aimed to contribute to our better understanding of potamoplankton communities. The development and spatio-temporal dynamics of potamoplankton have been considered in relation to hydrological factors (e.g., water discharge, water residence time, water temperature) (Pace et al. 1992; Sabri et al. 1993; Castel 1993; Basu \& Pick 1996; Kobayashi et al. 1998; Thorp \& Mantovani 2005), biotic interactions (Ietswaart et al. 1999; Thorp \& Casper 2003), chemical factors (Maria-Heleni et al. 2000), availability of storage zones (Saunders \& Lewis 1989; Basu \& Pick 1996; Reckendorfer et al. 1999; Schiemer et al. 2001) and damming (Vranovský 1997).

Although there is no general consensus regarding the most important regulating factor, many authors consider the flow regime as a deciding one. Zooplankton biomass was positively related to water residence time and/or negatively related to water discharge in numerous cases (Saunders \& Lewis 1988; Pace et al. 1992; Thorp et al. 1994; Basu \& Pick 1996; Baranyi et al. 2002), however, some studies have not supported these findings (Sabri et al. 1993; Castel 1993; Onwudinjo \&
Egborge 1994). Water residence time has been demonstrated as a driving force of zooplankton in lakes as well (Obertegger et al. 2007).

Generally, microcrustaceans play a secondary role in rivers as compared to rotifers, which is explained by the shorter generation time of Rotatoria (Akopian et al. 2002; Lair 2006) or rotifers are supposed to benefit indirectly from river turbidity because their crustacean competitors and predators are relatively more susceptible to suspended sediments (Thorp \& Mantovani 2005). Crustacean communities are often dominated by small-bodied cladocerans (e.g., bosminids) and juvenile forms (copepodite, nauplii) of copepods (Pourriot et al. 1997; Kobayashi et al. 1998; Reckendorfer et al. 1999; Kim \& Joo 2000). In channelized and regulated rivers, zooplankton production cannot be regarded important, rather the availability of storage zones determines plankton densities. This lentic origin of plankton organisms is well documented in some rivers (Naidenow 1998; Reckendorfer et al. 1999; Schiemer et al. 2001; Zsuga et al. 2004). The physical interaction of flow regime and river margin morphology determines the availability of inshore storage zones and the rate at which plankton are added to the main channel (Reckendorfer et al. 1999).

The distribution of zooplankton across a river is irregular in most cases (Naidenow 1971, 1979). Although no significant differences can be observed among the 


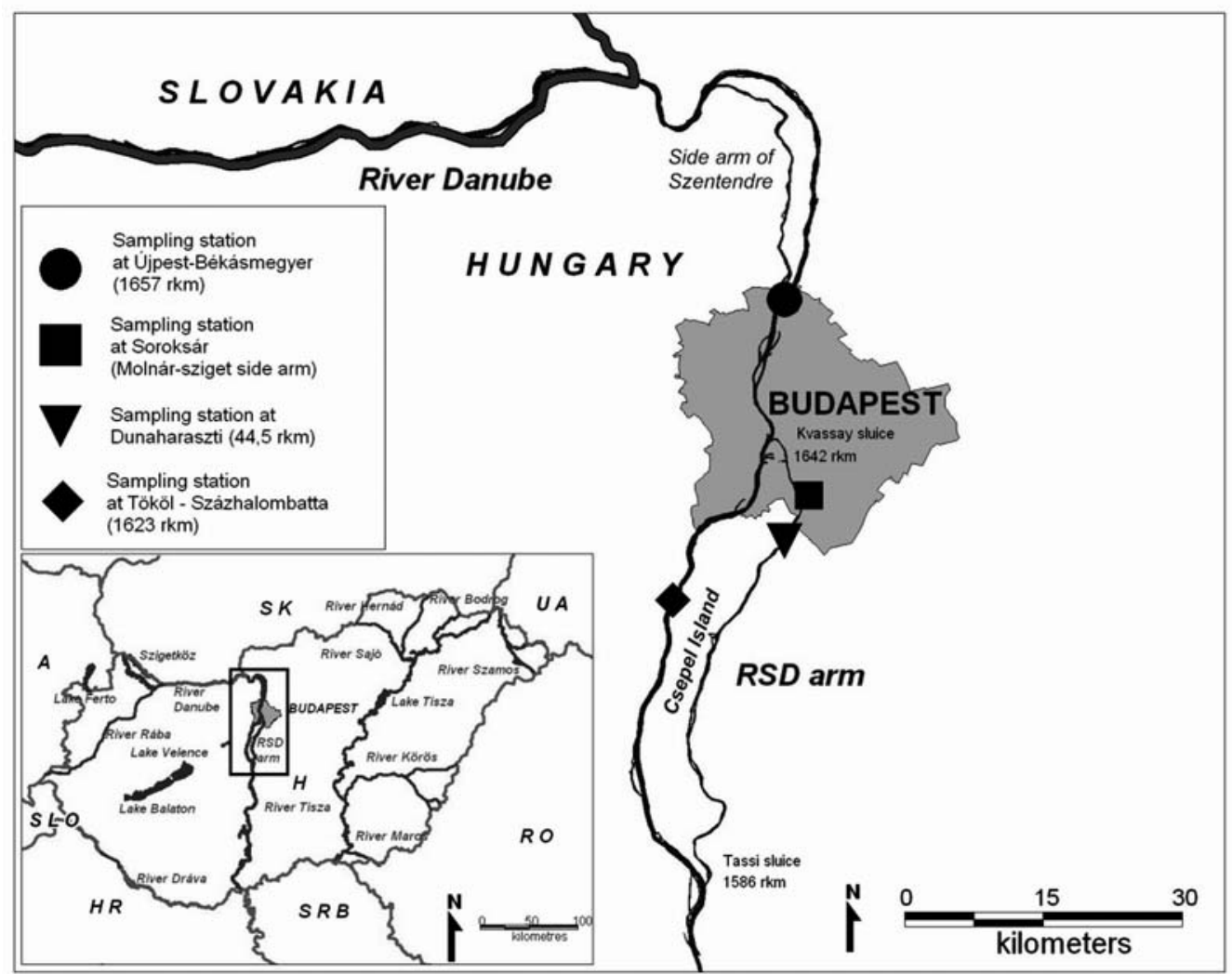

Fig. 1. Map of the sampling sites.

streamline and the banks, densities were found to be often higher nearshore (Bothár 1978, 1985; Thorp et al. 1994; Mitsuka \& Henry 2002). In principle, samples taken from the streamline can be regarded as a representative of the river (Gulyás \& Forró 1999).

The section of the Danube River near Budapest has been investigated regularly (Bothár 1978, 1988; Gulyás 1994, 1995), however, most of the studies were confined to the area of Göd (Bothár 1968, 1972, 1994, 1996) or included only short periods (Ponyi 1962; Gulyás 1997, 2002).

On the basis of the above-mentioned, we put emphasis on the target variables (water residence time, water discharge, water temperature) when discussing the results. Significant impact of the hydrological regime is expected, that is, increasing residence time favours zooplankton. Thus, densities are expected to decline when water discharge is relatively high. As for the spatial distribution of zooplankton, densities are supposed to vary both along (effect of the capital) and across (streamline vs. river bank) the river.

Present paper aimed to (1) quantify zooplankton densities in the Danube River and in its side arms; (2) measure target environmental variables in order to identify possible factors controlling crustacean density; (3) analyze the spatial patterns of microcrustacean assemblages with special regard to transversal distribution, potential differences between the profiles upstream and downstream Budapest and the differences between water bodies with distinct characters; (4) determine the seasonal dynamics of the crustacean plankton.
In order to achieve these goals, crustacean plankton was studied in the Danube River and in its side arms over 14 months at eleven sampling sites. The research included transversal sampling procedures both in the main arm and in the Ráckeve-Soroksár arm. The spatio-temporal dynamics of zooplankton and its relation to environmental variables were analysed with various statistical methods.

\section{Material and methods}

\section{Study sites}

The Danube River is the second largest river in Europe and is more than $2,800 \mathrm{~km}$ long with a catchment area of 817,000 $\mathrm{km}^{2}$. The Hungarian section is $417 \mathrm{~km}$ long. The RáckeveSoroksár Danube arm is the second largest side arm in the Hungarian section of the Danube River, and is located between $\mathrm{rkm} \mathrm{1,642}$ and 1,586. It is $58 \mathrm{~km}$ long from which $11 \mathrm{~km}$ belongs to the area of Budapest. It is enclosed by the two estaurine works Kvassay- and Tass sluices, therefore water level is manageable. The current velocity is very low, $0.1-0.3 \mathrm{~m} \mathrm{~s}^{-1}$ and the water level fluctuation is only between $20-60 \mathrm{~cm}$.

The present study was conducted in the main channel at two profiles upstream and downstream Budapest (ÚjpestBékásmegyer, 1657 rkm; Tököl-Százhalombatta, 1623 rkm), in the Ráckeve-Soroksár Danube (RSD) arm by Dunaharaszti ( $\mathrm{rkm} \mathrm{44.5)}$ and in the side arms of the RSD (Sportsziget and Molnár-sziget side arms) (Fig. 1). The sampling stations are summarized in Table 1 . The general characteristics of the two profiles in the main channel are similar, but the sampling site of Tököl-Százhalombatta is characterized by gravel banks interrupted occasionally with rip- 
Table 1. Sampling stations and their abbreviations.

\begin{tabular}{|c|c|c|c|}
\hline & & Sampling station & Abbreviation \\
\hline \multirow[t]{6}{*}{ Danube } & Side arm of Szentendre & Békásmegyer & $\mathrm{B}$ \\
\hline & Main channel & Ujpest-Békásmegyer streamline & UBS \\
\hline & & Újpest & $\mathrm{U}$ \\
\hline & & Tököl & $\mathrm{T}$ \\
\hline & & Tököl-Százhalombatta streamline & TSzS \\
\hline & & Százhalombatta & $\mathrm{Sz}$ \\
\hline \multirow[t]{5}{*}{$\mathrm{RSD}$} & Main channel & Dunaharaszti left bank & DL \\
\hline & & Dunaharaszti streamline & DS \\
\hline & & Dunaharaszti right bank & $\mathrm{DR}$ \\
\hline & Side arms & Sport-sziget side arm & SS \\
\hline & & Molnár-sziget side arm & MS \\
\hline
\end{tabular}

rap, whereas in the profile of Újpest-Békásmegyer rip-rap is the main component. The sampling point of Békásmegyer is situated in the downstream section of the Danube arm of Szentendre, near to the estuary into the main channel. The study site of Dunaharaszti extends in the upper stretch of the RSD arm. The features of this section are the following: the river bed is shallow $(2-3 \mathrm{~m})$ and narrow (80$200 \mathrm{~m}$ ). Shoreline vegetation is comprised by reeds, however, large-scale patchiness is typical of this section. The ground is formed by gravel and silt. The Sport-sziget side arm (SS) is a parapotamal type of water body, it is situated in the area of Dunaharaszti. The arm length is $500 \mathrm{~m}$, the width $20-30 \mathrm{~m}$ and the depth is about $1-1.5 \mathrm{~m}$. In the littoral zone, macrovegetation is formed mainly by reed, the siltation is remarkable. The Molnár-sziget side arm (MS) can be regarded as eupotamal. It is situated in the area of Soroksár (Budapest) between rkms 49-51, its length is $2000 \mathrm{~m}$, the width $20-50 \mathrm{~m}$, the depth $0.5-2 \mathrm{~m}$. The Sewage works of south Budapest are located some $200 \mathrm{~m}$ upstream from the estuary, which is the greatest source of pollution in the RSD arm and gives a considerable amount of nutrients and wash. Siltation is of great importance, moreover the silt in itself has a high nutrient content. Nevertheless, the extended reeds play an important role in the self-purification process.

The study sites were designated on the basis of our objectives that required different water bodies (main arm, different types of side arms), possibilities for transversal sampling (ferry, bridge), moreover sampling profiles upstream and downstream Budapest.

\section{Sampling and data analysis}

Samples were collected at biweekly intervals from October 2006 to November 2007 at eleven sampling sites. During the winter period (between December and February) zooplankton was sampled monthly. Samples were taken from the streamline, left side and right side of the main channel and of the Ráckeve-Soroksár side arm $(100 \mathrm{~L})$, whereas from the open water in the parapotamal and eupotamal side arms of the Ráckeve-Soroksár Danube (50 L). Samples were taken from the surface water layer and filtered through a plankton net (50 $\mu \mathrm{m}$ mesh size). The material collected was preserved in situ in $4 \%$ formaldehyde solution. A total of 302 samples was collected and analysed. In most cases all zooplankton were identified and counted, only the samples characterized with extremely high individual numbers (only in the parapotamal side arm by some of the samples collected in summer) were split into two parts after homogenizing, then one subsample was counted. Nauplii were counted in $5 \mathrm{ml}$ subsamples in special counting chambers after homogenization. For the taxonomic determination of the animals identification keys by Gulyás \& Forró (1999, 2001), Einsle (1993), Amoros (1984) and Dussart (1969) were used. Copepods and cladocerans were identified to species level, however, copepods belonging to the suborder Harpacticoida and ostracods were only counted.

Water temperature and conductivity were measured, while water discharge and water level data were obtained from the Environmental and Water Research Institute ("VITUKI"). Water residence time was calculated with the formula

$$
R=0.08 A_{\mathrm{d}}^{0.6} / Q^{0.1}
$$

where $R$ is the residence time at the sampling site (d), $A_{\mathrm{d}}$ is watershed area upstream of the sampling site $\left(\mathrm{km}^{2}\right)$, and $\mathrm{Q}$ is river discharge $\left(\mathrm{m}^{3} \mathrm{~s}^{-1}\right)$ (Soballe \& Kimmel 1987). We used the discharge data measured at Budapest (1646.5 $\mathrm{rkm})$.

In order to explore the spatial and temporal patterns, cluster analysis and non-metric multidimensional scaling (NMDS) using the Euclidean distance were performed (with standardized data). The bootstrap method was used to prepare our data for further statistical analyses. The bootstrap samples were analysed using NMDS to identify the similarity of the study sites and seasons. Data of biweekly interval were transformed as monthly average before the analysis. One-way ANOVA and post-hoc tests (LSD-Least Significant Difference, Tukey test) were applied to detect significant differences between seasons and sampling sites, respectively, based on the bootstrap samples. Normality and homogeneity of variance were tested (Normal Probability Plot, Levene's test) before using the methods mentioned above. In case of unequal variances, only the Tukey test was applied. $F$ - and $t$-tests were applied for some pairwise comparisons (left river bank vs. right river bank, river bank vs. stream line, the Danube vs. the RSD arm, the profile upstream Budapest vs. the profile downstream Budapest). In addition, Shannon diversity t-test was used to compare the diversity of the sampling sites. Linear correlation was used to detect any significant association between the target environmental variables and the zooplankton community. Significant differences were identified at $P<0.05$. All data analyses were performed using the PAST program (Hammer et al. 2001). 
Table 2. Data of hydrological regime and zooplankton abundance.

\begin{tabular}{|c|c|c|c|c|c|c|c|}
\hline \multicolumn{4}{|c|}{ Újpest-Békásmegyer } & \multicolumn{4}{|c|}{ Tököl-Százhalombatta } \\
\hline $\begin{array}{l}\text { Sampling } \\
\text { date }\end{array}$ & $\begin{array}{l}\text { Zooplankton } \\
\text { abundance } \\
\text { (ind. } 300 \mathrm{~L}^{-1} \text { ) }\end{array}$ & $\begin{array}{l}\text { Discharge } \\
\left(\mathrm{m}^{3} \mathrm{~s}^{-1}\right)\end{array}$ & $\begin{array}{l}\text { Residence time } \\
\text { (day) }\end{array}$ & $\begin{array}{l}\text { Sampling } \\
\text { date }\end{array}$ & $\begin{array}{l}\text { Zooplankton } \\
\text { abundance } \\
\text { (ind. } 300 \mathrm{~L}^{-1} \text { ) }\end{array}$ & $\begin{array}{l}\text { Discharge } \\
\left(\mathrm{m}^{3} \mathrm{~s}^{-1}\right)\end{array}$ & $\begin{array}{l}\text { Residence time } \\
\text { (day) }\end{array}$ \\
\hline 02.X.2006 & 30 & 1400 & 56.06 & 03.X.2006 & 32 & 1310 & 56.43 \\
\hline 16.X.2006 & 29 & 1240 & 56.74 & 17.X.2006 & 27 & 1200 & 56.93 \\
\hline 30.X.2006 & 13 & 1070 & 57.58 & 31.X.2006 & 12 & 1080 & 57.53 \\
\hline 13.XI.2006 & 0 & 1720 & 54.91 & 15.XI.2006 & 4 & 2170 & 53.65 \\
\hline 27.XI.2006 & 13 & 1650 & 55.14 & 28.XI.2006 & 15 & 1560 & 55.45 \\
\hline 11.XII.2006. & 0 & 1380 & 56.14 & 13.XII.2006 & 0 & 1460 & 55.82 \\
\hline 08.I.2007 & 0 & 1450 & 55.86 & 09.I.2007 & 2 & 1520 & 55.60 \\
\hline 05.II.2007 & 2 & 1860 & 54.49 & 06.II.2007 & 11 & 1780 & 54.73 \\
\hline 05.III.2007 & 22 & 3300 & 51.45 & 07.III.2007 & 1 & 3290 & 51.47 \\
\hline 21.III.2007 & 2 & 1910 & 54.34 & 21.III.2007 & 23 & 1910 & 54.34 \\
\hline 02.IV.2007 & 22 & 2190 & 53.60 & 04.IV.2007 & 32 & 2120 & 53.78 \\
\hline 16.IV.2007 & 26 & 1910 & 54.34 & 19.IV.2007 & 17 & 1810 & 54.64 \\
\hline 02.V.2007 & 3 & 1480 & 55.75 & 03.V.2007 & 25 & 1440 & 55.90 \\
\hline 14.V.2007 & 53 & 2500 & 52.90 & 16.V.2007 & 32 & 2110 & 53.80 \\
\hline 01.VI.2007 & 56 & 2210 & 53.56 & 31.V.2007 & 30 & 1730 & 54.88 \\
\hline 11.VI.2007 & 12 & 1850 & 54.52 & 13.VI.2007 & 61 & 1760 & 54.79 \\
\hline 26.VI.2007 & 20 & 1920 & 54.31 & 25.VI.2007 & 41 & 1860 & 54.49 \\
\hline 12.VII.2007 & 4 & 3120 & 51.74 & 09.VII.2007 & 11 & 2510 & 52.88 \\
\hline 20.VII.2007 & 2 & 1860 & 54.49 & 19.VII.2007 & 47 & 1900 & 54.37 \\
\hline 09.VIII.2007 & 120 & 1320 & 56.39 & 08.VIII.2007 & 65 & 1380 & 56.14 \\
\hline 24.VIII.2007 & 33 & 1850 & 54.52 & 23.VIII. 2007 & 11 & 1860 & 54.49 \\
\hline 07.IX.2007 & 14 & 2310 & 53.32 & 03.IX.2007 & 19 & 2130 & 53.75 \\
\hline 17.IX.2007 & 4 & 3880 & 50.62 & 18.IX.2007 & 7 & 3260 & 51.51 \\
\hline 02.X.2007 & 37 & 2420 & 53.07 & 01.X.2007 & 4 & 2310 & 53.32 \\
\hline 16.X.2007 & 2 & 1460 & 55.82 & 15.X.2007 & 20 & 1560 & 55.45 \\
\hline 29.X.2007 & 17 & 1730 & 54.88 & 30.X.2007 & 16 & 1940 & 54.26 \\
\hline 12.XI.2007 & 14 & 2360 & 53.20 & 13.XI.2007 & 41 & 2650 & 52.59 \\
\hline 29.XI.2007 & 20 & 2730 & 52.44 & 28.XI.2007 & 28 & 2820 & 52.27 \\
\hline
\end{tabular}

\section{Results}

During the study period, water temperature varied between 3.5 and $24^{\circ} \mathrm{C}$ in the main channel as well as in the RSD. In the side arms of the RSD it ranged between 3.5 and $26.5^{\circ} \mathrm{C}$. Conductivity increased in the RSD arm, but was the highest in the eupotamal and parapotamal side arms. Water level varied between 93 and $453 \mathrm{~cm}$ at Budapest, its fluctuation was negligible (about $30 \mathrm{~cm}$ ) in the RSD arm, whereas water discharge altered between $1070-3880 \mathrm{~m}^{3} \mathrm{~s}^{-1}$ at Budapest. Water level was the lowest in autumn both in 2006 and 2007, increased in the spring, followed by relatively lower values in the summer with a marked peak in July. However, the highest level was observed in September 2007, which was two times higher than other peaks. Water level fluctuation was in keeping with discharge values. Water residence time ranged between 50-57 days.

Data of hydrological regime and zooplankton abundance are presented in Table 2. There was a negative relationship between conductivity and water level both upstream and downstream Budapest $(r=-0.45, P<$ 0.05 , and $r=-0.42, P<0.05$, respectively). Zooplankton density was positively related to water temperature except for the Molnár-sziget side arm (Ujjpest $r=0.45$, $P<0.05$; Tököl $r=0.54, P<0.01$; RSD $r=0.44, P<$ 0.05 ; SS $r=0.77, P<0.001)$. No significant relationship was detected either between zooplankton density and water level or between zooplankton density and wa- ter discharge. Also water residence time proved not to be significantly related to zooplankton abundance.

A total of 49 species were detected from which 35 were cladocerans and 14 copepods (Table 3 ). In addition, ostracods and Harpacticoida were also recorded and included in the analysis, but they were not identified to species level. Frequent species included Alona rectangula, Alona quadrangularis, Bosmina longirostris, Chydorus sphaericus, Moina micrura, Acanthocyclops robustus, Eucyclops serrulatus, Thermocyclops crassus. Moina micrura contributed up to $32.7 \%$ of the total zooplankton community, while B. longirostris and T. crassus added up to $14.8 \%$ and $10.1 \%$ of the total density, respectively. Bosmina coregoni, Pseudochydorus globosus, Pleuroxus denticulatus, P. truncatus, Diacyclops bicuspidatus, Paracyclops affinis proved to be rare species in the investigated period. During the survey, the relative contributions of the main taxa to the whole zooplankton community were the undermentioned: Cladocera 52\%; Copepoda adult 17\%; copepodite $14 \%$; nauplii $16 \%$. In the main channel, the relative contribution to total zooplankton abundance were $20 \%$ of cladocera, $18 \%$ of adult copepods, $15 \%$ of copepodites, and $47 \%$ of copepod nauplii. Zooplankton dynamics is presented in Figs 2-6 together with water temperature and residence time (in case of the main channel of the Danube River).

The dendogram of the cluster analysis indicated (Fig. 7) that the parapotamal (SS) and eupotamal (MS) 
Table 3. Zooplankton taxa recorded in the Danube River and in its side arms.

\begin{tabular}{|c|c|c|c|c|c|c|c|c|c|c|c|}
\hline Taxa & $\mathrm{DR}$ & DS & DL & SS & MS & $\mathrm{B}$ & UBS & $\mathrm{U}$ & $\mathrm{S}$ & TSS & $\mathrm{T}$ \\
\hline \multicolumn{12}{|l|}{ Cladocera } \\
\hline Alona affinis (Leydig, 1860) & & & + & & & & & & & & \\
\hline Alona guttata Sars, 1862 & + & & & & + & + & & & & & + \\
\hline Alona intermedia Sars, 1862 & & & & + & + & + & & & & & \\
\hline Alona quadrangularis (O.F. Müller, 1785) & + & + & + & + & + & + & + & + & + & & + \\
\hline Alona rectangula Sars, 1862 & + & + & + & + & + & + & + & + & + & + & + \\
\hline Bosmina coregoni Baird, 1857 & + & & & & & & & & & & \\
\hline Bosmina longirostris (O.F. Müller, 1785) & + & + & + & + & + & + & + & + & + & + & + \\
\hline Ceriodaphnia pulchella Sars, 1862 & + & & & & & & & & & & \\
\hline Ceriodaphnia quadrangula (O.F. Müller, 1785) & + & & + & + & & & & & & & \\
\hline Chydorus sphaericus (O.F. Müller, 1776) & + & + & + & + & + & + & + & + & & + & \\
\hline Daphnia cucullata Sars, 1862 & + & & + & + & + & + & + & + & + & + & + \\
\hline Daphnia longispina O.F. Müller, 1785 & & & & + & + & + & + & + & & + & \\
\hline Diaphanosoma brachyurum (Liévin, 1848) & + & & + & + & + & + & & + & & & \\
\hline Diaphanosoma mongolianum Uéno, 1938 & + & & + & + & + & & & & & & \\
\hline Disparalona rostrata (Koch, 1841) & + & + & + & + & + & & & + & & & \\
\hline Eurycercus lamellatus (O.F. Müller, 1785) & & & + & & & & & & & & \\
\hline Graptoleberis testudinaria (Fischer, 1848) & + & + & + & + & + & + & & & & & \\
\hline Iliocryptus agilis Kurz, 1878 & + & + & + & + & + & & & & & & \\
\hline Iliocryptus sordidus (Liévin, 1848) & + & & + & + & + & & & & + & + & \\
\hline Leydigia acanthocercoides (Fischer, 1854) & + & + & + & + & & & & & & & + \\
\hline Leydigia leydigi (Schoedler, 1863) & + & + & + & & + & & & + & + & & \\
\hline Macrothrix hirsuticornis Norman et Brady, 1867 & + & & + & & & & & + & & & \\
\hline Macrothrix laticornis (Fischer, 1848) & + & + & + & & + & & & + & & & + \\
\hline Moina macrocopa (Straus, 1820) & & & + & + & + & + & & + & & & \\
\hline Moina micrura Kurz, 1874 & + & + & + & + & + & + & + & + & + & & + \\
\hline Oxyurella tenuicaudis (Sars, 1862) & + & + & & & & & & & & & \\
\hline Pleuroxus aduncus (Jurine, 1820) & + & + & + & + & + & & & & + & & + \\
\hline Pleuroxus denticulatus Birge, 1879 & & + & + & & & & & & & & \\
\hline Pleuroxus truncatus (O.F. Müller, 1785) & & & + & & & & & & & & \\
\hline Pleuroxus uncinatus Baird, 1850 & + & & + & + & & & & & & & \\
\hline Pseudochydorus globosus (Baird, 1843) & + & + & + & & & & & & & & \\
\hline Scapholeberis mucronata (O.F. Müller, 1785) & + & & + & + & + & + & & & & & \\
\hline Sida crystallina (O.F. Müller, 1776) & + & & & & & & & & & & + \\
\hline Simocephalus serrulatus (Koch, 1841) & + & & & & & & & & & & \\
\hline Simocephalus vetulus (O.F. Müller, 1776) & + & + & + & & + & + & & & & & \\
\hline \multicolumn{12}{|l|}{ Copepoda } \\
\hline \multicolumn{12}{|l|}{ Calanoida } \\
\hline Eudiaptomus gracilis (Sars, 1863) & & + & & & + & & + & & & & + \\
\hline Eurytemora velox (Lilljeborg, 1853) & + & & & + & + & + & & + & + & + & + \\
\hline \multicolumn{12}{|l|}{ Cyclopoida } \\
\hline Acanthocyclops robustus (Sars, 1863) & + & + & + & + & + & + & + & + & + & + & + \\
\hline Acanthocyclops vernalis (Fischer, 1853) & & & & & & & & & & + & \\
\hline Cyclops strenuus Fischer, 1851 & + & & + & + & + & & & & + & & + \\
\hline Diacyclops bicuspidatus (Claus, 1857) & & & & + & & & & & & & \\
\hline Eucyclops macruroides (Lilljeborg, 1901) & + & & & & + & & & & & & \\
\hline Eucyclops serrulatus (Fischer, 1851) & + & + & + & + & + & + & + & & + & & + \\
\hline Eucyclops speratus (Lilljeborg, 1901) & & & & & + & & & & & & \\
\hline Macrocyclops albidus (Jurine, 1820) & + & & & & + & & & & & & \\
\hline Mesocyclops leuckarti (Claus, 1857) & & & & + & & + & & & & & \\
\hline Paracyclops affinis (Sars, 1863) & & & & & + & & & & & & \\
\hline Paracyclops fimbriatus (Fischer, 1853) & + & + & + & + & + & + & & + & & & + \\
\hline Thermocyclops crassus (Fischer, 1853) & + & + & + & + & + & + & + & + & + & + & + \\
\hline Harpacticoida & + & + & + & + & + & + & + & + & + & + & + \\
\hline Ostracoda & + & & + & + & + & + & & + & & & + \\
\hline
\end{tabular}

side arms are separated from the other sampling sites. In addition, the sampling site B seemed to form a single group as compared to the other samling sites in the main channel and RSD arm. The RSD arm is not separated entirely since the left bank (DL) proved to be more similar to the sampling sites of the main arm. The NMDS analysis confirmed the above-mentioned findings. The eupotamal side arm of the RSD (MS) was characterized by the dominance of Moina micrura, Chydorus sphaericus, Diaphanosoma mongolianum, Simocephalus vetulus, Eucyclops serrulatus, and Thermo- cyclops crassus. Dominant species in the SS included T. crassus, M. micrura, B. longirostris, Alona rectangula. In the main channel T. crassus, Acanthocyclops robustus, B. longirostris, A. rectangula, $M$. micrura, Daphnia cucullata and Harpacticoida were predominant, whereas in the RSD arm T. crassus, E. serrulatus, M. micrura, B. longirostris, C. sphaericus, Leydigia leydigi, Disparalona rostrata, A. rectangula, $A$. quadrangularis dominated.

Looking at the average densities per sampling sites (Table 4) three groups can be distinguished. The main 


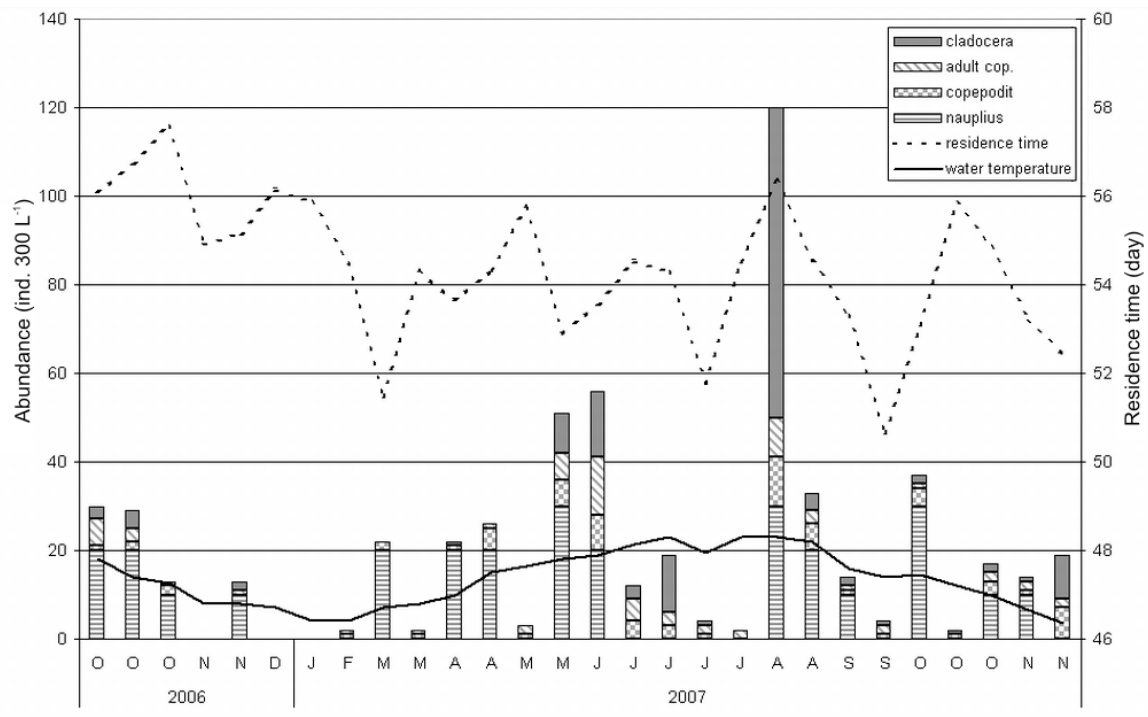

Fig. 2. Abundances of the main zooplankton groups, water temperature and residence time recorded over the study period (sampling profile Újpest-Békásmegyer).

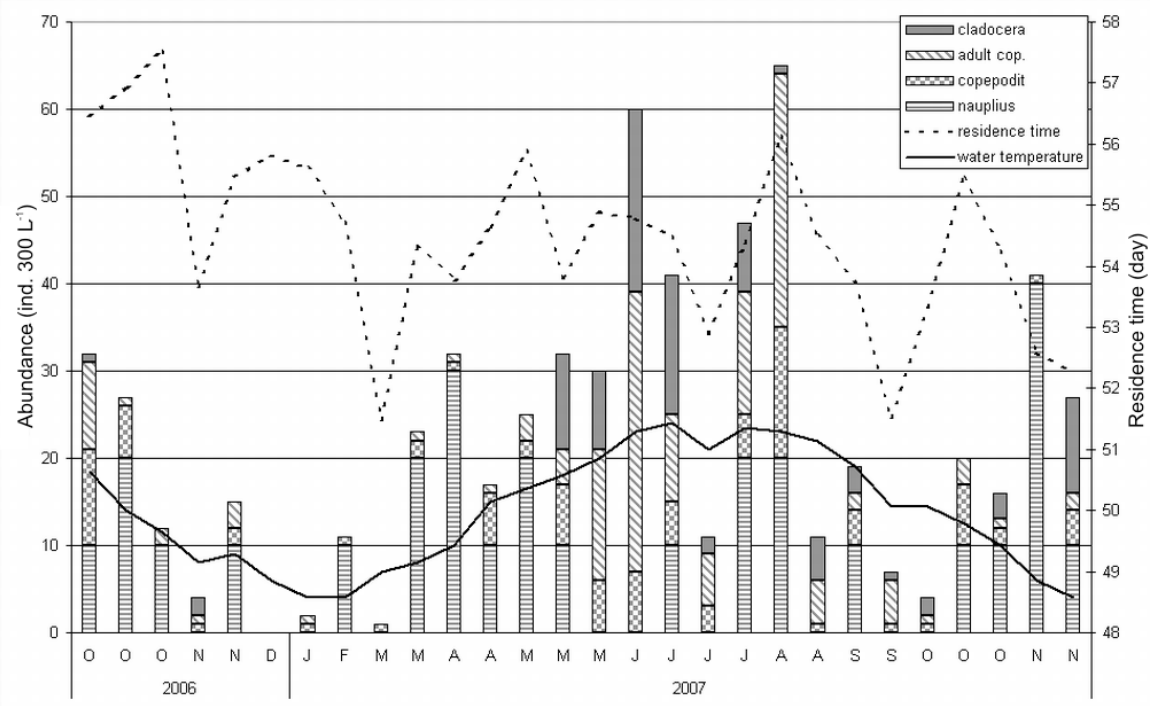

Fig. 3. Abundances of the main zooplankton groups, water temperature and residence time recorded over the study period (sampling profile Tököl-Százhalombatta).

Table 4. Average individual numbers of the major zooplankton groups and dominant species (ind. $\mathrm{m}^{-3}$ ).

\begin{tabular}{lrrrrrrr}
\hline Sites & Cladocera & Nauplius & Copepoda adult & Copepodit & $\begin{array}{c}\text { Thermocyclops } \\
\text { crassus }\end{array}$ & $\begin{array}{c}\text { Moina } \\
\text { micrura }\end{array}$ & $\begin{array}{c}\text { Bosmina } \\
\text { longirostris }\end{array}$ \\
\hline DL & 84.29 & 125.00 & 20.71 & 29.29 & 4.29 & 4.64 & 22.50 \\
DS & 48.93 & 78.57 & 6.79 & 51.07 & 0.71 & 7.86 & 16.07 \\
DR & 189.64 & 128.57 & 95.36 & 106.79 & 34.64 & 12.14 & 10.36 \\
T & 18.21 & 42.86 & 25.71 & 14.64 & 10.71 & 1.79 & 10.36 \\
TSS & 5.00 & 25.00 & 5.71 & 5.71 & 0.71 & 0.00 & 1.79 \\
S & 10.71 & 32.14 & 22.86 & 15.36 & 8.57 & 0.71 & 1.43 \\
U & 13.93 & 46.43 & 8.57 & 12.14 & 0.71 & 0.71 & 3.57 \\
UBS & 7.86 & 21.43 & 10.00 & 8.21 & 1.43 & 2.86 & 1.07 \\
B & 30.00 & 32.14 & 5.71 & 5.71 & 0.36 & 20.36 & 0.71 \\
SS & 4301.60 & 1664.00 & 3072.80 & 2333.60 & 1848.80 & 853.60 & 3003.20 \\
MS & 6152.80 & 1064.00 & 332.80 & 301.60 & 192.80 & 5898.40 & 8.00 \\
\hline
\end{tabular}

channel is characterized by very low abundance, an increase in abundance of one order of magnitude was observed in the RSD arm, whereas the densities in the side arms (MS, SS) are two orders of magnitude higher. However, in the side arm MS, densities of planktonic crustaceans did not differ from the RSD in such a 


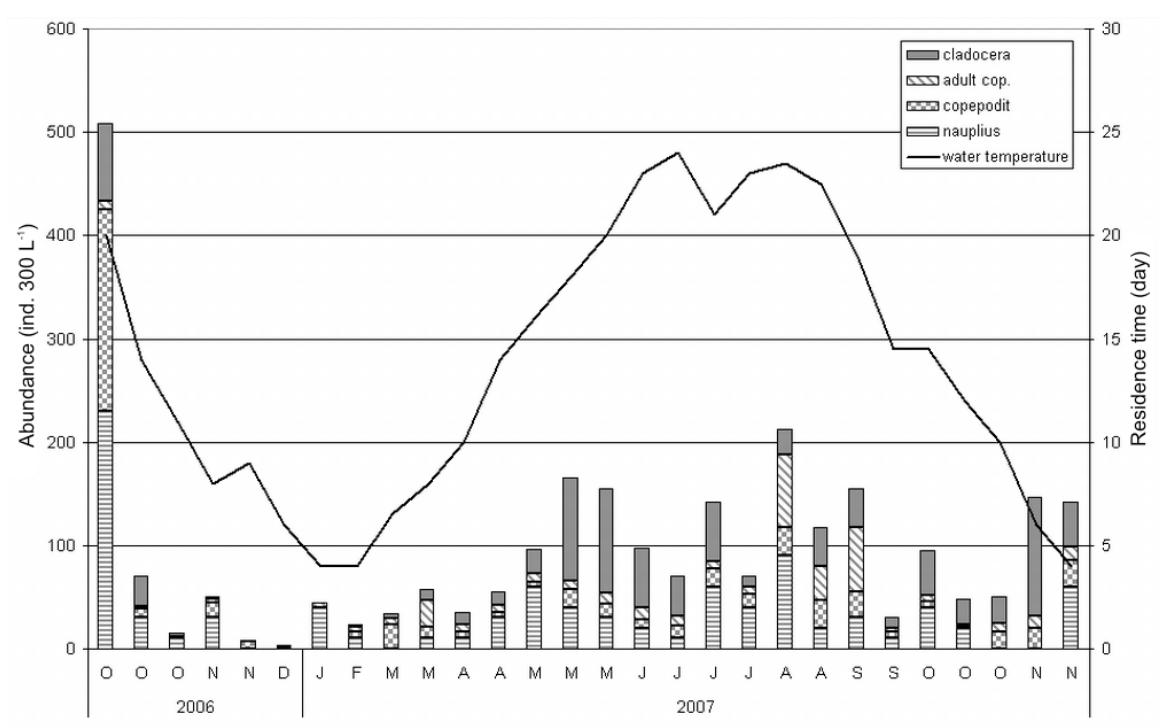

Fig. 4. Abundances of the main zooplankton groups and water temperature recorded over the study period (sampling profile Dunaharaszti).

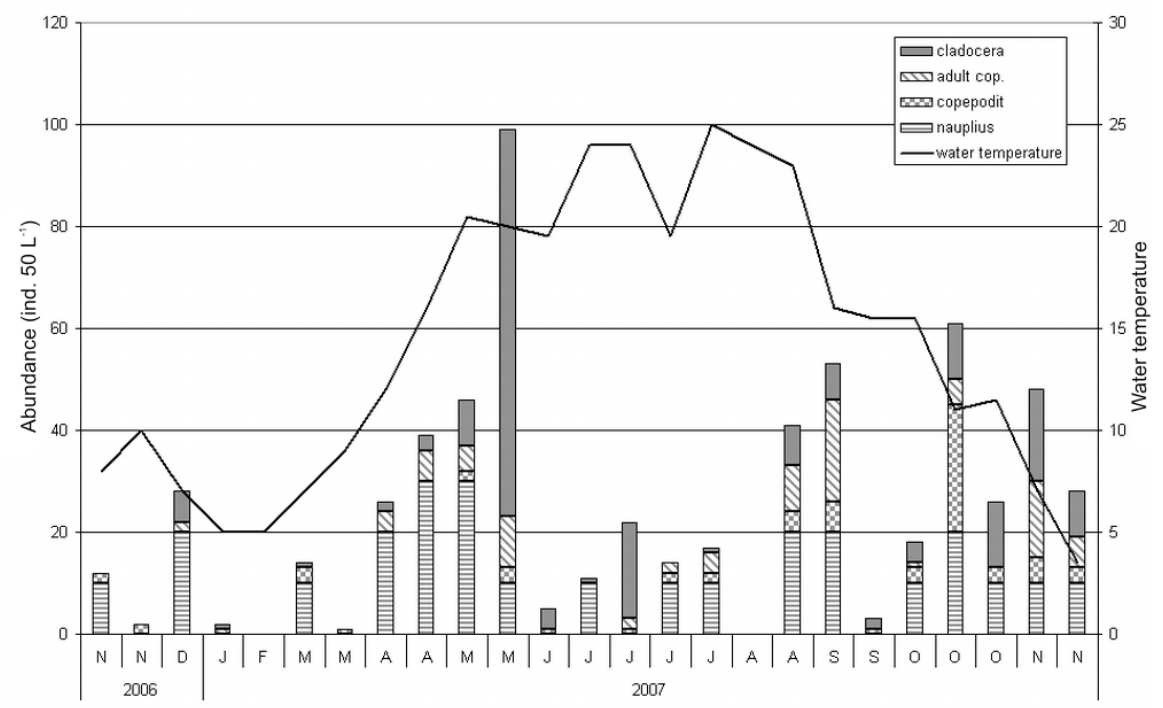

Fig. 5. Abundances of the main zooplankton groups and water temperature recorded over the study period (Molnár-sziget side arm). Sample taken at 09 August has a total abundance of 9198 ind. $50 \mathrm{~L}^{-1}$, thus this point is not included in the figure.

large extent except for one sampling. This sample taken in August was characterized by extrem high individual numbers of $M$. micrura, but other frequent species peaked by this time as well. Densities in the streamline were generally lower compared to the littoral, but marked deviations occured only in the RSD arm.

The spatial distribution of the zooplankton community were analyzed in many aspects, namely we put emphasis both on the longitudinal and transversal distribution in the main channel, additionally the main arm and the RSD arm was also compared. Table 5 shows the results of $t$-tests for the main taxa. The pairwise comparisons included (1) the profile upstream Budapest vs. the profile downstream Budapest (longitudinal pattern); (2) river bank vs. stream line; (3) left river bank vs. right river bank; (4) the Danube vs. the RSD arm. No general pattern exists, the spatial differences depend on the investigated objects, e. g. in case of longitudinal patterns the three dominant species and adult copepods differ significantly in their abundance between the two profiles (Tököl-Százhalombatta, UjpestBékásmegyer), whereas copepodites, nauplii and cladocerans do not indicate remarkable longitudinal differences. Significant differences were observed between the river bank and the streamline in case of adult copepod, cladoceran, T. crassus and M. micrura densities. Futhermore, the abundance of adult copepods, nauplii, M. micrura and B. longirostris showed significant differences between the right and the left bank of the Danube River. The RSD arm differed from the main channel regarding adult copepod, copepodite, cladoceran, $M$. micrura and B. longirostris densities.

One-way ANOVA and Tukey's pairwise comparisons were performed to detect any significance differ- 


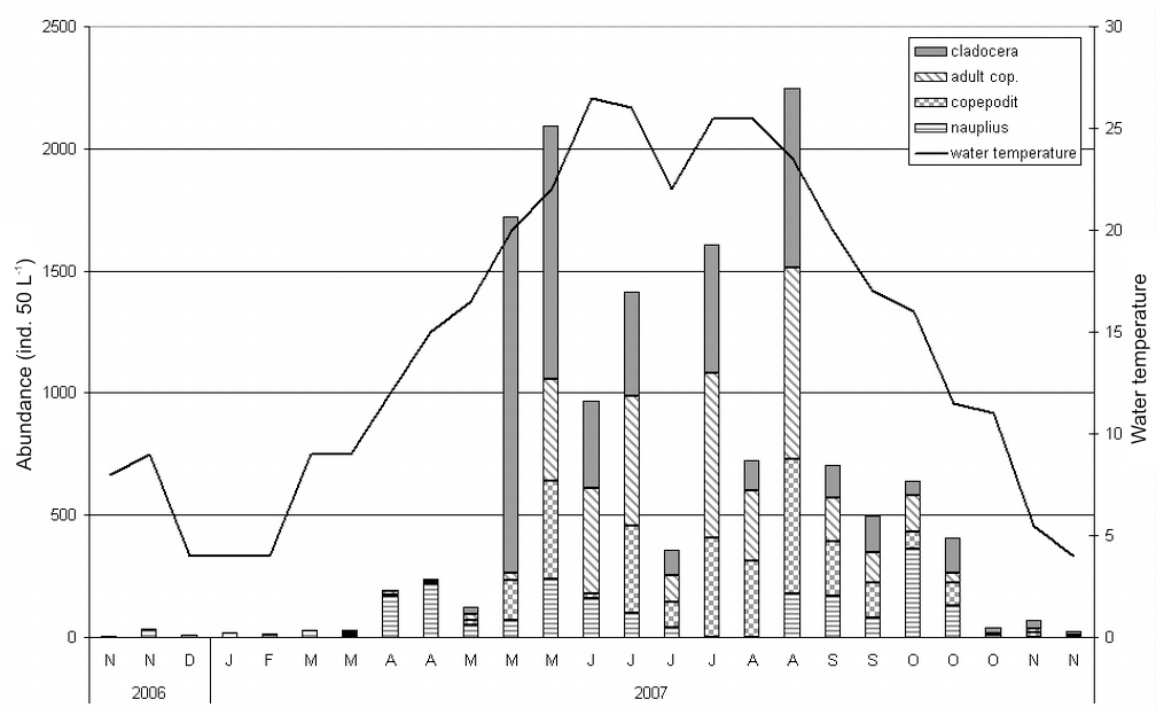

Fig. 6. Abundances of the main zooplankton groups and water temperature recorded over the study period (Sport-sziget side arm).

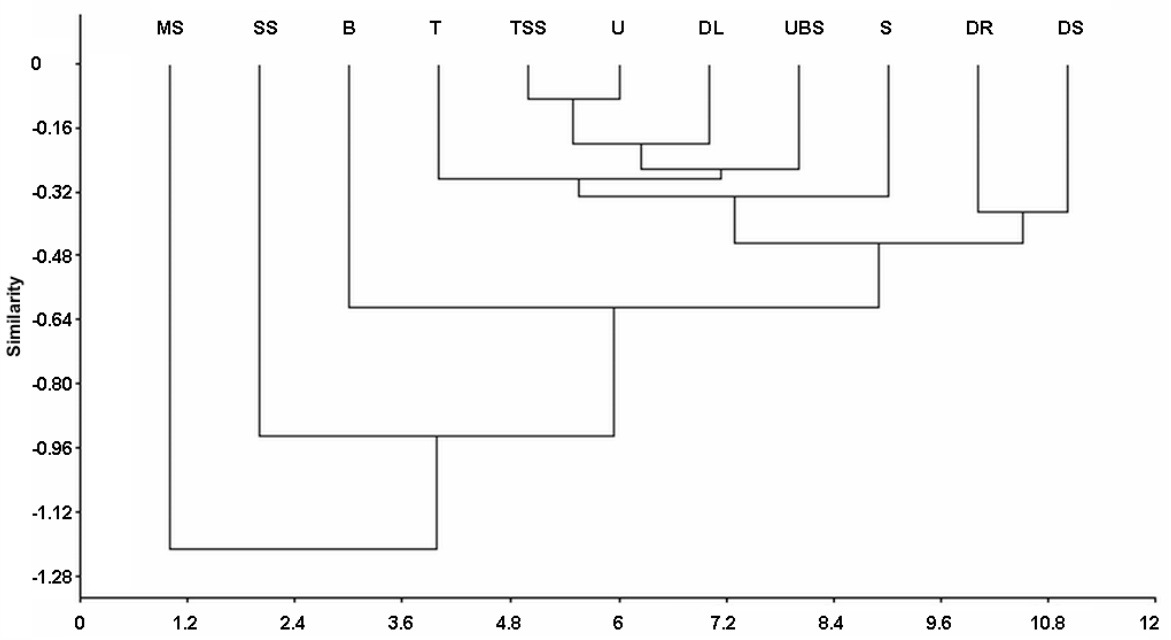

Fig. 7. The dendogram of the sampling sites (Euclidean distance).

Table 5 . Results of the $t$-test for the main taxa. Significant values are marked with bold characters.

\begin{tabular}{lcccc}
\hline Taxa & Longitudinal & Bank-Streamline & Left-Right Banks & Danube-RSD \\
\hline Copepoda adult & $\mathbf{0 . 0 3 7 4}$ & $\mathbf{0 . 0 0 0 2}$ & $\mathbf{0 . 0 0 3 1}$ & $\mathbf{0 . 0 0 0 1}$ \\
Copepodit & 0.1169 & 0.2557 & 0.6570 & $\mathbf{0 . 0 0 0 8}$ \\
Nauplius & 0.4542 & 0.3305 & $\mathbf{0 . 0 1 1 2}$ & 0.5389 \\
Cladocera & 0.6884 & $\mathbf{0 . 0 0 3 6}$ & 0.7568 & $\mathbf{0 . 0 0 0 0}$ \\
Thermocyclops crassus & $\mathbf{0 . 0 0 0 1}$ & $\mathbf{0 . 0 0 0 2}$ & $\mathbf{0 . 0 0 0 7}$ & 0.1157 \\
Moina micrura & $\mathbf{0 . 0 0 0 0}$ & $\mathbf{0 . 0 0 1 9}$ & $\mathbf{0 . 0 0 4 6}$ & $\mathbf{0 . 0 0 1 2}$ \\
Bosmina longirostris & $\mathbf{0 . 0 0 7 8}$ & 0.4803 & $\mathbf{0 . 0 4 0 5}$ \\
\hline
\end{tabular}

ences between the sampling sites. The objects of similarity were the densities of the above-mentioned groups except $M$. micrura, because its abundance was 0 in the sampling site of TSS. Examining the profile of Dunaharaszti in the RSD arm, only two significant differences can be observed: densities of adult copepods differed between the right bank and streamline $(P=0.004)$, as well as $B$. longirostris densities differed between the left and right bank $(P=0.006)$. SS and MS in- dicated significant differences from most of the sampling sites, however, SS did not show any significant differences in case of copepodites. The Shannon diversity $t$-test resulted in the following findings: the sampling sites MS and SS differed significantly from the others in their Shannon diversity, but the B in case of SS. Other significant differences included: DL-DS; DL-T; DL-TSS; DL-S; DL-UBS; DL-B; DS-DR; DSB. Moreover, DR differed from each sampling sites 


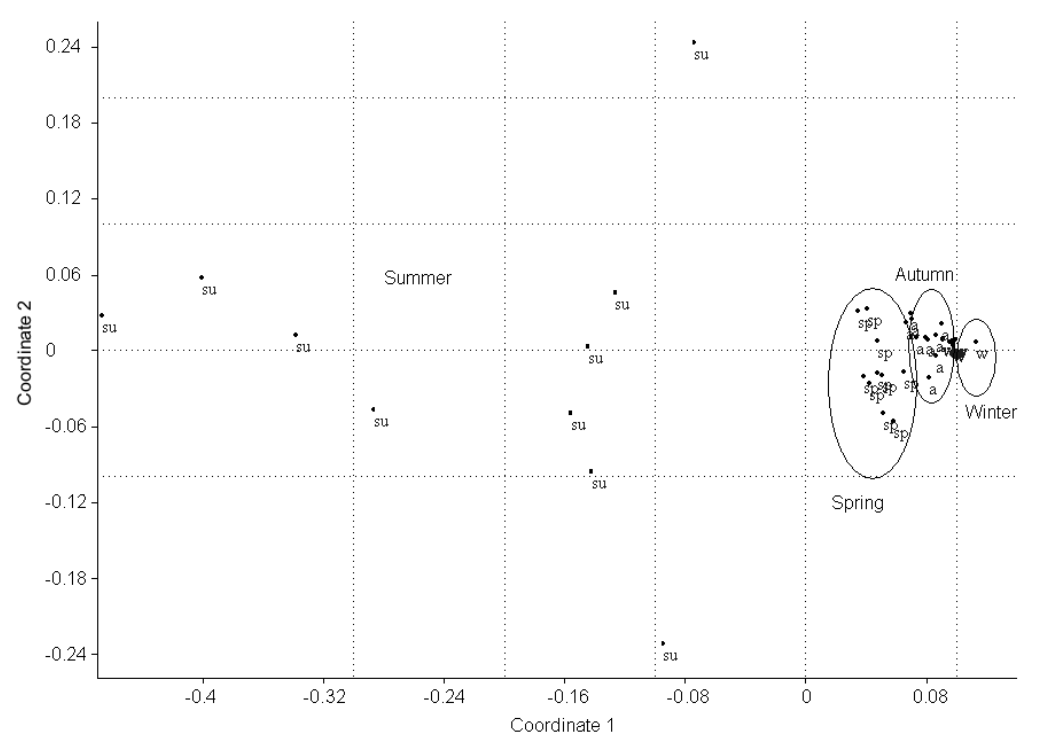

Fig. 8. The NMDS plot of the bootstrap samples (Euclidean distance).

except DL; U differed from T, TSS, S, UBS and B.

Figure 8 shows the temporal pattern of the investigated waters uniformly, based on the bootstrap samples. Only the year of 2007 was taken into consideration and included in the analysis, since for the previos year we have few data. It is conspicuous that samples taken in summer have a larger variation, but form a single group. However, samples taken in spring and autumn are separated from each other and from summer samples as well. Winter samples also form a group, nevertheless, they seem to take place within samples taken in autumn. Adult copepod, copepodite, nauplius and cladoceran densities all showed significant seasonal differences. That is, samples taken in summer differed significantly from samples taken in spring, autumn and winter, however, there were no other differences between seasons based on the findings of the Tukey test.

Winter was characterized by low abundance, even the most abundant taxa were missing ( $T$. crassus, $M$. micrura, B. longirostris). This population decline was best professed by the side arms. Spring samples did not contain one of the dominant species, namely $M$. micrura and cladoceran densities were relatively lower as compared to summer and autumn 2007. In summer, adult copepods, cladocerans, T. crassus and M. micrura reached high abundance, whereas the individual numbers of nauplii and copepodites remained lower. Adult copepods occured with relatively lower individual numbers in autumn.

\section{Discussion}

Our results did not imply strong relationship between zooplankton density and the hydrological regime, but pointed out the evidence of spatial heterogeneity both between and within the examined water bodies. Although a weak negative relationship was detected be- tween zooplankton density and water discharge and a weak positive relationship was found between crustacean abundance and water residence time, respectively, these relationships were not nearly significant. This suggests that other abiotic and biotic factors may effect crustacean density. The time available for zooplankton to develop was esimated at 50-57 days (an estimate of the time the water has been in the river system) assuming that plankton drifts with the current passively. During this time 5 generations of cladocerans and 1-2 generations of copepods may develop (Naidenow 1998). The growth is supposed to depend on the hydrological regime (increased residence time favours zooplankton and zooplankton benefits from low water velocity, respectively). This is not only due to the mechanical effect of the drift, but is connected with the fact, that suspended matters have a negative impact on planktonic crustaceans (Gulyás 2002; Zsuga et al. 2004). Our results suggest (lack of relationships between zooplankton abundance and water residence time, respectively discharge) that zooplankton production in the main channel is of minor importance which is consistent with the findings of Reckendorfer et al. (1999). Floodplain areas and adjacent water bodies seem to be rather important sources of plankton biomass (Saunders \& Lewis 1989; Naidenow 1998; Schiemer et al. 2001). However, it is worth mentioning, that the present study is confined only to microcrustacean plankton, and it is well-known that zooplankton communities in rivers are often dominated by rotifers (Gulyás 1995 - Danube River; Burger et al. 2002 - Waikato River; Kim \& Joo 2000 - Nakdong River; Maria-Heleni et al. 2000 - Aliakmon River; Saunders \& Lewis 1988 - Apure River; Saunders \& Lewis 1989 Orinoco River; Van Dijk \& Zanten 1995 - Rhine River; Thorp et al. 1994 - Ohio River).

The dominant species that were found in the present study in the main channel (Acanthocyclops robustus, Bosmina longirostris) are consistent with the 
findings of Bothár $(1985,1988,1994)$ and Gulyás (1994, 1995), however, the relatively large contributions of Thermocyclops crassus and Harpacticoida are something new. Two thermophyl species, Thermocyclops crassus and M. micrura are reported to become abundant in the Danube River since 1971 (Bothár 1975), but they were regarded only as secondary species at Göd (rkm 1669) (Bothár 1985). Their high densities in the Sport-sziget side arm and Molnár-sziget side arm in summer can be explained by the high water temperature. The first occurrence of Eurytemora velox in the Hungarian section of the main channel was reported in 1992 at rkm 1669 (Bothár 1994), since then it has been spread in the main arm (Gulyás 1995) as well as in the RSD arm (Just et al. 1998). Present study confirmed the expansion of this species. In Hungary, Pleuroxus denticulatus has only been reported from the Szigetköz region (Gulyás \& Forró 1999), but has been depected as an invador in the Slovakian floodplain area (Illyová \& Némethová 2005). The dominance of the smallbodied cladoceran Bosmina longirostris, nauplii and copepodites are in keeping with the findings of Gulyás (1994, 1995) and Bothár $(1978,1994)$ but the relative contribution of copepodites is rather low in this study (it is almost equal to those of adult copepods), nevertheless, Bothár (1978) got to similar results. Generally, planktonic crustacean assemblages in the Danube River are characterized by 30-40\% of larvae (Bothár 1975). Quantitatively, the low individual numbers that were found in the present study are consistent with that of Bothár et al. (1971) and Bothár (1978) at UjpestBékásmegyer, but not with Gulyás's results (1994).

The eupotamal and parapotamal side arms of the RSD are separated, the side arm of Szentendre is separated from the other sampling sites as well. This suggests that the side arms have distinct features both qualitatively and quantitatively. There were notable differences in zooplankton abundances between the side arms (SS, MS), the RSD and the main channel. The separation of the sampling site B (side arm of Szentendre) is attributable to several species (Alona intermedia, Graptoleberis testudinaria, Scapholeberis mucronata, Simocephalus vetulus and Mesocyclops leuckarti) that were not recorded in the main channel. Mesocyclops leuckarti was only detected here. Only the relatively high individual numbers of $M$. micrura involved notable quantitative differences between the main channel and the side arm of Szentendre. The sampling site DR was characterized by the highest Shannon diversity whereas the MS the lowest. These values explain the results of the Shannon diversity t-test. The high diversity of the right bank can be attributable to the macrovegetation (reed). Differences in Shannon diversity exist between the streamline and the banks in the case of the RSD and partly at the profile of Ujpest-Békásmegyer, but not at TökölSzázhalombatta. Generally, the streamline is characterized by appreciably lower values, but it is not true for the profile of Ujpest-Békásmegyer. The RSD arm has a more diverse zooplankton community as compared to the Danube River and the parapotamal and eupotamal side arms. Definitely, this is due to the favourable environment of the RSD (low current velocity, macrovegetation, minimal water level fluctuation, self-purification). At the same time, lower velocities contribute to the deposition of a fine, organic sediment, which favours benthic organisms, what is more, light conditions are better as well (Bothár 1980). The Molnár-sziget side arm is more closed to the Sewage works of South Budapest, thus pollution may influence the community. Although the dominance of some pollution resistant species (e.g., Chydorus sphaericus) seems to support this hypothesis, the extrem high densities of $M$. micrura indicate that pollution is not intense.

General distribution patterns could not be found regarding zooplankton densities, the spatial differences depended on the examined objects. However, there were several significant differences in the densities of the main taxa both across and along the examined river section. The RSD arm also showed some remarkable differences from the main channel. The distribution of zooplankton across a river is irregular in most cases (Naidenow 1971, 1979). Although no significant differences can be observed among the streamline and the banks, densities were found to be often higher nearshore (Bothár 1978, 1985; Thorp et al. 1994; Mitsuka \& Henry 2002). In principle, samples taken from the streamline can be regarded as a representative of the river ( $\mathrm{Gu}-$ lyás \& Forró 1999). Our results supported these findings to some extent. In conclusion, spatial patterns of zooplankton assemblages should be evaluated considering taxonomic aspects, habitat types, hydrological conditions, human impacts. The authors stress the importance of side arms as source of planktonic crustaceans both in qualitative and quantitative points of view.

\section{Acknowledgements}

The authors would like to thank K. Bodolai, P. Gulyás, Á. Berczik and M. Dinka for their assistance. We wish to thank the crews of the ferries of Tököl-Százhalombatta and ÚjpestBékásmegyer for their help by sampling. We are grateful for support of the Environmental and Water Research Institute (VITUKI).

\section{References}

Akopian M., Garnier J. \& Pourriot R. 2002. Cinétique du zooplancton dans un continuum aquatique: de la Marne et son réservoir a l' estuaire de la Seine. C. R. Biologies 325: 807818.

Amoros C. 1984. Introduction pratique à la systématique des eaux continentales francaises. 5. Crustacés cladocères. Bull. Mens. Soc. Linn. Lyon 53: 1-63.

Baranyi C., Hein T., Holarek C., Keckeis S. \& Schiemer F. 2002. Zooplankton biomass and community structure in a Danube River floodplain system: effects of hydrology. Freshwater Biol. 47: 473-482. DOI 10.1046/j.1365-2427.2002.00822.x

Basu B.K. \& Pick F.R. 1996. Factors regulating phytoplankton and zooplankton biomass in temperate rivers. Limnol. Oceanogr. 41: 1572-1577.

Bothár A. 1968. Untersuchungen des Donauplanktons an Entomostraca während der grossen Überschwemmung im Jahre 
1965. Danub. Hung. XLVIII. Ann. Univ. Sci. Budapest. Sect. Biol. 9-10: 87-98.

Bothár A. 1972. Hydrobiologische Untersuchungen im Nebenarm der Donau bei Göd. Danub. Hung. LXII. Ann. Univ. Sci. Budapest. Sect. Biol. 13: 9-23.

Bothár A. 1975. Die Änderungen der Crustacea-Gemeinschaften des Planktons aufgrund der im Donauabschnitt von Göd (Stromkm 1669) durchgeführten Untersuchungen. Danub. Hung. LXXVIII. Ann. Univ. Sci. Budapest. Sect. Biol. 17: $137-146$.

Bothár A. 1978. Crustacea-Planktonuntersuchungen im Donauabschnitt zwischen Szob und Nagymaros (Stromkm 17071656). Danub. Hung. LXXXVIII. Ann. Univ. Sci. Budapest. Sect. Biol. 20-21: 249-259.

Bothár A. 1980. Vergleichende Untersuchung der CrustaceaGemeinschaften im Nebenarm "Alte Donau" und im Hauptstrom (Stromkm 1481). Danub. Hung. XCIX. Ann. Univ. Sci. Budapest. Sect. Biol. 22-23: 159-174

Bothár A. 1985. Die qualitative und quantitative Verbreitung der planktonischen Crustaceen im ungarischen Donauabschnitt von 1965-1985, pp. 283-287. In: Wiss. Kurzref., 25. Arbeitstagung der IAD, Bratislava, Slowakei.

Bothár A. 1988. Quantitative und qualitative Zooplanktonuntersuchungen im Donauabschnitt oberhalb und unterhalb von Budapest I. J. 1987, pp. 179-182. In: Wiss. Kurzref., 27. Arbeitstagung der IAD, Mamaia, Romania.

Bothár A. 1994. Qualitative und quantitative Planktonuntersuchungen in der Donau bei Göd/Ungarn (1669 Stromkm) II. Zooplankton, pp. 41-44. In: Wiss. Kurzref., 30. Arbeitstagung der IAD, Zuoz, Schweiz.

Bothár A. 1996. Die lang- und kurzfristigen Änderungen in der Gestaltung des Zooplanktons (Cladocera, Copepoda) der Donau - Probeentnahmestrategien, pp. 201-206. In: Wiss. Ref. 1, 31. Arbeitstagung der IAD, Baja, Ungarn.

Bothár A., Dvihally Z.T. \& Kozma E.V. 1971. Hydrobiologische Untersuchungen im Donauabschnitt zwischen Nagymaros und Megyer (Stromkm 1695-1656). Danub. Hung. LVII. Ann. Univ. Sci. Budapest. Sect. Biol. 13: 5-18.

Burger D.F., Hogg I.D. \& Green J.D. 2002. Distribution and abundance of zooplankton in the Waikato River, New Zealand. Hydrobiologia 479: 31-38. DOI 10.1023/A:1021064 111587

Castel J. 1993. Long-term distribution of zooplankton in the Gironde estuary and its relation with river flow and suspended matter. Cah. Biol. Mar. 34: 145-163.

Dussart B. 1969. Les Copepodes des Eaux Continentales II: Cyclopoides et Biologie. Ed. N. Boubee \& Cie, Paris, 292 pp.

Einsle U. 1993. Crustacea, Copepoda: Calanoida und Cyclopoida. In: Schwoerbel J. \& Zwick P. (eds), Süsswasserfauna von Mitteleuropa, Bd. 8, Heft 4, Teil 1, Gustav Fischer Verlag, Stuttgart, 208 pp.

Gulyás P. 1994. Studies on the Rotatorian and Crustacean plankton in the Hungarian section of the Danube between 1848,4 and 1659,0 riv. km, pp. 49-61. In: Kinzelbach R. (ed.), Biologie der Donau, Gustav Fischer, Stuttgart.

Gulyás P. 1995. Rotatoria and Crustacea plankton of the River Danube between Bratislava and Budapest. Misc. Zool. Hung. 10: $7-19$.

Gulyás P. 1997. Untersuchungen des Rotatoria- und CrustaceaPlanktons an der Donaustrecke unterhalb Budapest sowie im Donauarm Ráckevei-Soroksári Duna (RSD), pp. 265-270. In: Wiss. Ref. 1, 32. Arbeitstagung der IAD, Wien, Österreich.

Gulyás P. 2002. A Rotatoria és Crustacea plankton minőségi és mennyiségi vizsgálata a Dunán. Vízügyi Közl. 84: 601-620.

Gulyás P. \& Forró L. 1999. Az ágascsápú rákok (Cladocera) kishatározója, 2. bővített kiadás. Vízi Természet- és Környezetvédelem, 9. kötet, Környezetgazdálkodási Intézet, Budapest, 237 pp.

Gulyás P. \& Forró L. 2001. Az evezőlábú rákok (Calanoida és Cyclopoida) alrendjeinek kishatározója, 2. bővített kiadás. Vízi Természet- és Környezetvédelem, 14. kötet, Környezetgazdálkodási Intézet, Budapest, 198 pp.

Hammer O.D., Harper A.T. \& Ryan P.D. 2001. PAST: Paleontological Statistics software package for education and data analysis. Paleont. Electron. 4 (1): 1-9.
Ietswaart T.H., Breebaart L., Van Zanten B. \& Bijkerk R. 1999. Plankton dynamics in the river Rhine during downstream transport as influenced by biotic interactions and hydrological conditions. Hydrobiologia 410: 1-10. DOI 10.1023/A:100380 1110365

Illyová M. \& Némethová D. 2005. Long-term changes in cladoceran assemblages in the Danube floodplain area (SlovakHungarian stretch). Limnologica 35: 274-282. DOI 10.1016/ j.limno.2005.08.004

Just I., Schöll F. \& Tittizer T. (ed.) 1998. Versuch einer Harmonisierung nationaler Methoden zur Bewertung der Gewassergüte im Donauarm am Beispiel der Abwasser der Stadt Budapest. Umweltbundesamt, Berlin, Texte 53/98, 65 pp.

Kim H.W. \& Joo G.J. 2000. The longitudinal distribution and community dynamics of zooplankton in a regulated large river: a case study of the Nakdong River (Korea). Hydrobiologia 438: 171-184. DOI 10.1023/A:1004185216043

Kobayashi T., Shiel R.J., Gibbs P. \& Dixon P.I. 1998. Freshwater zooplankton in the Hawkesbury-Nepean River: comparison of community structure with other rivers. Hydrobiologia 377: 133-145. DOI 10.1023/A:1003240511366

Lair N. 2006. A review of regulation mechanisms of metazoan plankton in riverine ecosystems: aquatic habitat versus biota. Riv. Res. Appl. 22: 567-593. DOI 10.1002/rra.923

Maria-Heleni Z., Michaloudi E., Bobori D.C. \& Mourelatos S. 2000. Zooplankton abundance in the Aliakmon River, Greece. Belg. J. Zool. 130: 29-33.

Mitsuka P.M. \& Henry R. 2002. The fate of copepod populations in the Paranapanema River (Sao Paulo, Brazil), downstream from the Jurumirim dam. Braz. Arch. Biol. Technol. 45: 479490.

Naidenow W. 1971. Zustand und Perspektiven der Untersuchungen über das Zooplankton der Donau, ihrer Nebenflüsse und der stehenden Gewässer. Schweiz. Z. Hydrol. 33: 314-321.

Naidenow W. 1979. Ein Beitrag zur Kenntnis des Zooplanktons der ungarischen Donau. Hidrobiologiya 9: 38-43.

Naidenow W. 1998. Das Zooplankton der Donau, pp. 163-248. In: Kusel-Fetzmann E., Naidenow W. \& Russev B. (eds), Plankton und Benthos der Donau, Ergebnisse der DonauForschung, Band 4, Wien.

Obertegger U., Flaim G., Braioni M.G., Sommaruga R., Corradini F. \& Borsato A. 2007. Water residence time as a driving force of zooplankton structure and succession. Aquat. Sci. 69: 575-583. DOI 10.1007/s00027-007-0924-z

Onwudinjo C.C. \& Egborge A.B.M. 1994. Rotifers of Benin River, Nigeria. Hydrobiologia 272: 87-94. DOI 10.1007/BF00006514

Pace M.L., Findlay S.E.G. \& Lints D. 1992. Zooplankton in advective environments: the Hudson River community and a comparative analysis. Can. J. Fish. Aquat. Sci. 49: 10601069.

Ponyi E. 1962. Beiträge zur Kenntnis des Crustaceen-Planktons der ungarischen Donau (Danub. Hung. XIV.). Opusc. Zool. Budapest 4: 127-132.

Pourriot R., Rougier C. \& Miquelis A. 1997. Origin and development of river zooplankton: example of the Marne. Hydrobiologia 345: 143-148. DOI 10.1023/A:1002935807795

Reckendorfer W., Keckeis H., Winkler G. \& Schiemer F. 1999. Zooplankton abundance in the River Danube, Austria: the significance of inshore retention. Freshwater Biol. 41: 583591. DOI 10.1046/j.1365-2427.1999.00412.x

Sabri A.W., Ali Z.H., Shawkat S.F., Thejar L.A., Kassim T.I. \& Rasheed K.A. 1993. Zooplankton population in the river Tigris - effects of Samarra impoundment. Reg. Riv. Res. Manage. 8: 237-250. DOI 10.1002/rrr.3450080304

Saunders J.F. \& Lewis W.M. 1988. Zooplankton abundance and transport in a tropical white-water river. Hydrobiologia 162: 147-155. DOI 10.1007/BF00014537

Saunders J.F. \& Lewis W.M. 1989. Zooplankton abundance in the lower Orinoco River, Venezuela. Limnol. Oceanogr. 34: 397-409.

Schiemer F., Keckeis H., Reckendorfer W. \& Winkler G. 2001. The inshore retention concept and its significance for large rivers. Arch. Hydrobiol. 135: 509-516. 
Soballe D.M. \& Kimmel B.L. 1987. A large-scale comparison of factors influencing phytoplankton abundance in rivers, lakes, and impoundments. Ecology 68: 1943-1954. DOI $10.2307 / 1939885$

Thorp J.H. \& Casper A.F. 2003. Importance of biotic interactions in large rivers: an experiment with planktonivorous fish, dreissenid mussels and zooplankton in the St Lawrence River. Riv. Res. Appl. 19: 265-279. DOI 10.1002/rra.703

Thorp J.H. \& Mantovani S. 2005. Zooplankton of turbid and hydrologically dynamic prairie rivers. Freshwater Biol. 50: 1474-1491. DOI 10.1111/j.1365-2427.2005.01422.x

Thorp J.H., Black A.R., Haag K.H \& Wehr J.D. 1994. Zooplankton assemblages in the Ohio River: seasonal, tributary, and navigation dam effects. Can. J. Fish. Aquat. Sci. 51: 16341643. DOI $10.1139 /$ f94-164
Van M. Dijk \&. Van Zanten B. 1995. Seasonal changes in zooplankton abundance in the lower Rhine during 1987-1991. Hydrobiologia 304: 29-38. DOI 10.1007/BF2530701

Vranovský M. 1997. Impact of the Gabcikovo hydropower plant operation on planktonic copepods assemblages in the River Danube and its floodplain downstream of Bratislava. Hydrobiologia 347: 41-49. DOI 10.1023/A:1002990705205

Zsuga K., Tóth A., Pekli J. \& Udvari Z. 2004. A Tisza vízgyüjtő zooplanktonjának alakulása az 1950-es évektől napjainkig. Hidrol. Közl. 84: 175-178.

Received January 23, 2009 Accepted May 15, 2009 